\title{
The role of peri-urban wetland and meadow habitats in the protection of trans-Saharan migrant passerine species in a central European city
}

\author{
Grzegorz Kopij
}

\begin{abstract}
Densities were estimated for several passerine longdistance migrant species associated with peri-urban wetlands and meadows in the city of Wroclaw $\left(293 \mathrm{~km}^{2}\right)$, SW Poland. Acrocephalus arundinaceus, A. scirpaceus, Locustella naevia and Lanius collurio nested in a crude density of more than 0.2 pairs/territorial males per 100 ha. The group of four other species (Saxicola torquatus, Locustella fluviatilis, L. luscinioides and Acrocephalus schoenobaenus) bred in a crude density between 1.1 and 1.5 pairs per $10 \mathrm{~km}^{2}$. The least numerous were the Sylvia nisoria (0.06 pairs per $100 \mathrm{ha}$ ) and Remiz pendulinus (0.02 pairs per 100 ha). Most of these species nested in the city in higher crude density than in a neighbouring rural area, richer of suitable habitats. Most breeding pairs occupied extensive peri-urban wetlands and meadows. These habitats could play an important role in conservation of these trans-Saharan migrants, as well as other water and marshland bird species. Such habitats are postulated to be protected as nature reserves or Special Protection Areas of the Natura 2000 .
\end{abstract}

Key words: urban ornithology, nature conservation, Acrocephalus, Locustella, population estimation, Wroclaw, Silesia.

Riassunto - Il ruolo delle zone umide peri-urbane e degli ambienti prativi nella protezione delle specie di passeriformi trans-sahariane in una città dell'Europa centrale.

Sono state stimate le densità di diverse specie di passeriformi migratori su lunga distanza associate a zone umide peri-urbane e prati nella città di Breslavia (Wroclaw), SW Polonia $\left(293 \mathrm{~km}^{2}\right)$. Acrocephalus arundinaceus, A. scirpaceus, Locustella naevia e Lanius collurio nidificano con densità di oltre 0,2 coppie (o maschi territoriali) per 100 ha Il gruppo di quattro altre specie (Saxicola torquatus, Locustella fluviatilis, L. luscinioides e Acrocephalus schoenobaenus) nidificano con densità tra 1,1 e 1,5 coppie per $10 \mathrm{~km}^{2}$. I meno numerosi erano Sylvia nisoria (0,06 coppie per 100 ha) e Remiz pendulinus (0,02 coppie per $100 \mathrm{ha})$. La maggior parte di queste specie nidifica in città con densità più elevate rispetto ad aree rurali limitrofe, più ricche di habitat adatti. La maggior parte delle coppie riproduttive occupava vaste zone umide peri-urbane e prati. Questi habitat potrebbero svolgere un ruolo importante nella conservazione di questi migratori tran-

Department of Vertebrate Ecology, Wroclaw University of Environmental \& Life Sciences, Wroclaw, Poland.

Department of Integrated Environmental Sciences, University of Namibia, Ogongo Campus, Namibia.

E-mail: gkopij@unam.na

(C) 2018 Grzegorz Kopij

Received: 3 October 2016

Accepted for publication: 10 Dicember 2017 sahariani e di altre specie di uccelli acquatici e palustri. Se presenti in qualsiasi città, tali habitat hanno le caratteristiche per essere protetti come riserve naturali o ZPS-Zone di Protezione Speciale di Rete Natura 2000.

Parole chiave: ornitologia urbana, conservazione della natura, Acrocephalus, Locustella, stime di popolazione, Breslavia.

\section{INTRODUCTION}

Wetlands and meadows play a crucial role in most ecosystems throughout the world. They purify and retain water and regulate its level, comprise important recreation areas, and provide habitats for numerous plant and animal species (Boyer \& Polasky, 2004). The Habitat Directive (92/43/EEC) and the Bird Directive (79/409/ EEC and 2009/147/EU) adopted by the E.U. Member States, ensures the protection of some rare, threatened and declining bird species in such habitats, for example the Barred Warbler Sylvia nisoria, Aquatic Warbler Acrocephalus paludicola, and Red-backed Shirke Lanius collurio.

However, many other small passerine species, occurring in such habitat, require special protection. Most of them, as trans-Saharan migrants, are vulnerable to mass mortality both on passage and in their wintering grounds. Also in their Palearctic breeding range, they are often threatened by habitat destruction (melioration), adverse weather conditions (droughts) and high predation pressure (e.g. wild boar Sus scrofa, raccoon dog Nyctereutes procyonoides, American mink Neovison vison, coypu Myocastor coypus and brown rat Rattus norvegicus) and human disturbance (BirdLife International, 1994; Angelici et al., 2012; Kopij, 2017).

Unexpectedly, around some large urban centres, extensive areas of such habitats remained, have been enlarged, modified or even created anew for water retention, and as anti-flood polders (Boyer \& Polasky, 2004). Wroclaw, a city in SW Poland, is a good example of such urbanized landscape with large areas of wetlands and meadows. The purpose of this paper was to estimate population densities of some passerine species associated with these habitats, and compare the obtained figures with those from a rural area in the same region. This is done in order to show the role of peri-urban marshlands and meadows in the protection of birds. 


\section{Study area}

The city of Wroclaw (SW Poland) within its administrative boundaries has a surface area of $293 \mathrm{~km}^{2}$ and the human population of about 640000 inhabitants (in 2004). It is situated in the large Odra Valley, where four other smaller rivers (Oława, Slęża, Bystrzyca and Widawa) join the Odra river. There are lots of grasslands and wetlands along these rivers.

In 2004 , arable land comprised $44.8 \%$ of the total surface area in Wroclaw, whereas 5.6\% were covered by forests and wooded areas, $3.4 \%$ by water, $9.8 \%$ by roads, $18.7 \%$ by built-up areas, $3.7 \%$ by gardens, $6.1 \%$ by recreational areas, and $1.3 \%$ by wastelands (data from the city government). Marshlands and meadows comprise together 6.6\% (Smolnicki \& Szykasiuk, 2002).

There is a large wetland area (about 1000 ha) in the south-eastern periphery of the city. It comprises a network of dams, backwaters, canals, and rivers amidst wet meadows and sedges, with some clumps of willows Salix spp., poplars Populus spp. and reed-beds (Kopij, 2008). It plays a role as a water retention area. Water (on average 160 thousand $\mathrm{m}^{3}$ per 24 hours) is pumped to the city and utilized by people. Another wetland, with the surface area of 1422 ha, is situated in the north-western periphery of the city. It comprises a sewage farm, with numerous dams, reed-beds and canals amidst mowed grasslands (Słychan, 1996; Orłowski \& Sęk, 2005; Orłowski et al., 2008).

The climate of Wroclaw is temperate, slightly warmer than in the neighbouring areas. The mean annual temperature is $9.7^{\circ} \mathrm{C}$, with the monthly mean of the coldest month (January) $-0.5^{\circ} \mathrm{C}$, and the warmest month (July) $19.9^{\circ} \mathrm{C}$. Mean annual precipitation is $548 \mathrm{~mm}$. Mean annual humidity is $76 \%$. There are, on average, 158 days with rains per year, and 1670 hours with sunny weather per year. The snow cover lasts on average 35 days per year (Smolnicki \& Szykasiuk, 2002).

\section{MATERIALS AND METHODS}

A simplified version of the territory mapping method (Bibby et al., 2012) has been employed to plot on maps occupied territories of some species associated with meadows and wetlands as their breeding and feeding habitats. All such habitats within the administrative boundaries of Wrocław (Fig. 1) were surveyed at least four times in breeding seasons (April-July). Different parts of the city were surveyed in different years. Some of them were covered by Kopij (2004, 2005, 2007, 2008, 2010, 2014a, 2014b, 2014c, $2016 \mathrm{c}$ ). All parts were covered within the period from 2002 to 2010 . Total research effort was about 180 days.

The following territorial species were censused: Great Reed Warbler Acrocephalus arundinaceus, Eurasian Reed Warbler A. scirpaceus, Sedge Warbler A. schoenobaenus, Grasshopper Warbler Locustella naevia, River Warbler L. Aluviatilis, Savi's Warbler L. luscinioides, Red-backed Shrike, Barred Warbler, Penduline Tit Remiz pendulinus, and Stonechat Saxicola torquatus.

Each seen or heard individual was plotted on the map 1: 10 000. Special attention was paid to simultaneously singing males and birds performing other territorial and/

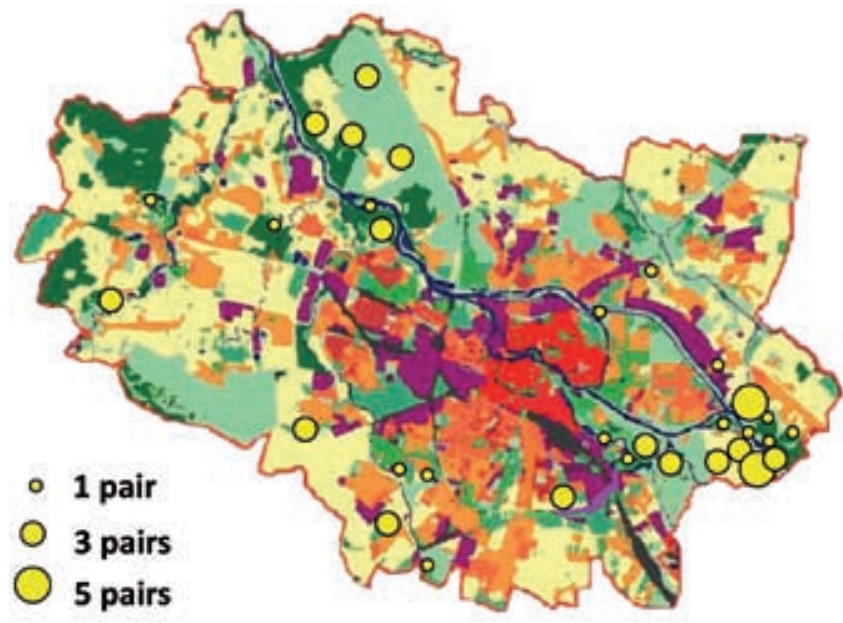

Fig. 1 - Distribution of Red-backed Shrike breeding pairs in the city of Wrocław during the years 2002-2010. Black) railway; purple) industry areas; red) densely built-up areas; orange) loosely built-up areas; dark green) urbanized woods; light green) parks; bright green) grassy areas; yellow) arable grounds. (Source, Smolnicki \& Szykasiuk, 2002). / Distribuzione delle coppie riproduttive di Averla piccola nella città di Breslavia negli anni 2002-2010. Nero) ferrovia, viola) aree industriali, rosso) aree densamente popolate, arancione) aree scarsamente popolate, verde scuro) boschi urbanizzati, verde chiaro) parchi, verde brillante) aree erbose, giallo) seminativi. (Fonte, Smolnicki \& Szykasiuk, 2002).

or breeding behaviour. At least two records of a bird at the same site, made in, at least, two-week-interval, were assumed as representing an occupied territory (Bibby et al., 2012). For each species, an estimation of the crude density (calculated per whole surface area of the city, i.e. $29300 \mathrm{ha}$ ) was obtained (as pairs/100 ha). Also the proportions among pairs belonging to the Locustella and Acrocephalus genera were calculated in Wrocław site, and compared to the same ratio obtained for neighbouring areas.

Maps were generated to show the distribution of breeding pairs of all species under the study. The distribution is shown on the background of habitats in the city of Wrocław, so as to descriptively elucidate habitat preferences. The map with different land uses were obtained from Smolnicki \& Szykasiuk (2002).

\section{RESULTS}

Contrary to the expectation, relatively high densities of breeding pairs of passerine species (especially from the genus Locustella), associated with marshland and meadow habitats, have been recorded in the city of Wrocław. The most numerous among studied species were the Great Reed Warbler, Eurasian Reed Warbler, Grasshopper Warbler and the Red-backed Shrike. All of them exceeded the crude density of 0.2 pairs per 100 ha. The group of four other species (Stonechat, River Warbler, Savi's Warbler and Sedge Warbler) bred in the crude density between 0.11 and 0.15 pairs per 100 ha. The least numerous were the Barred Warbler (0.06 pairs per $100 \mathrm{ha}$ ) and the Penduline Tit (0.02 pairs per 100 ha).

The wetlands comprise also habitat for numerous other water and wetlands birds, such as the White Stork Ciconia ciconia, Common Crane Grus grus, Corncrake Crex 
crex, Bluethoat Luscinia svecica, Reed Bunting Emberiza schoeniclus (Słychan et al., 1996; Orłowski \& Sęk, 2005; Orłowski et al., 2008; Kopij, 2016b).

Most breeding pairs of all those species occurred in three areas: 1) polders with numerous sewage dams in the
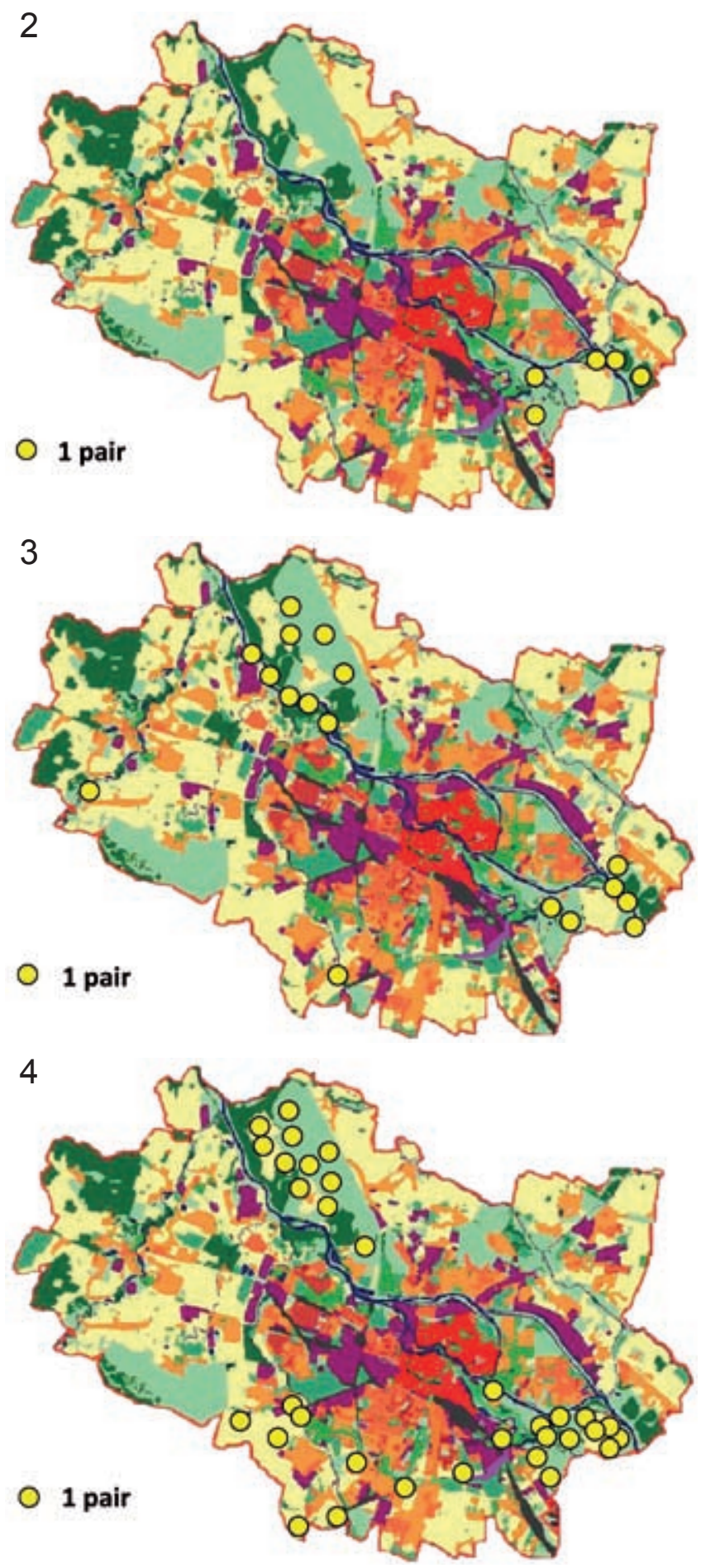

NW part between Odra and Widawa rivers; 2) wetlands in the SE part between Odra and Oława rivers; 3) along Odra river. Some pairs nested also along smaller rivers and on larger water bodies, especially those situated in the western part of the city (Figs. 1-10).
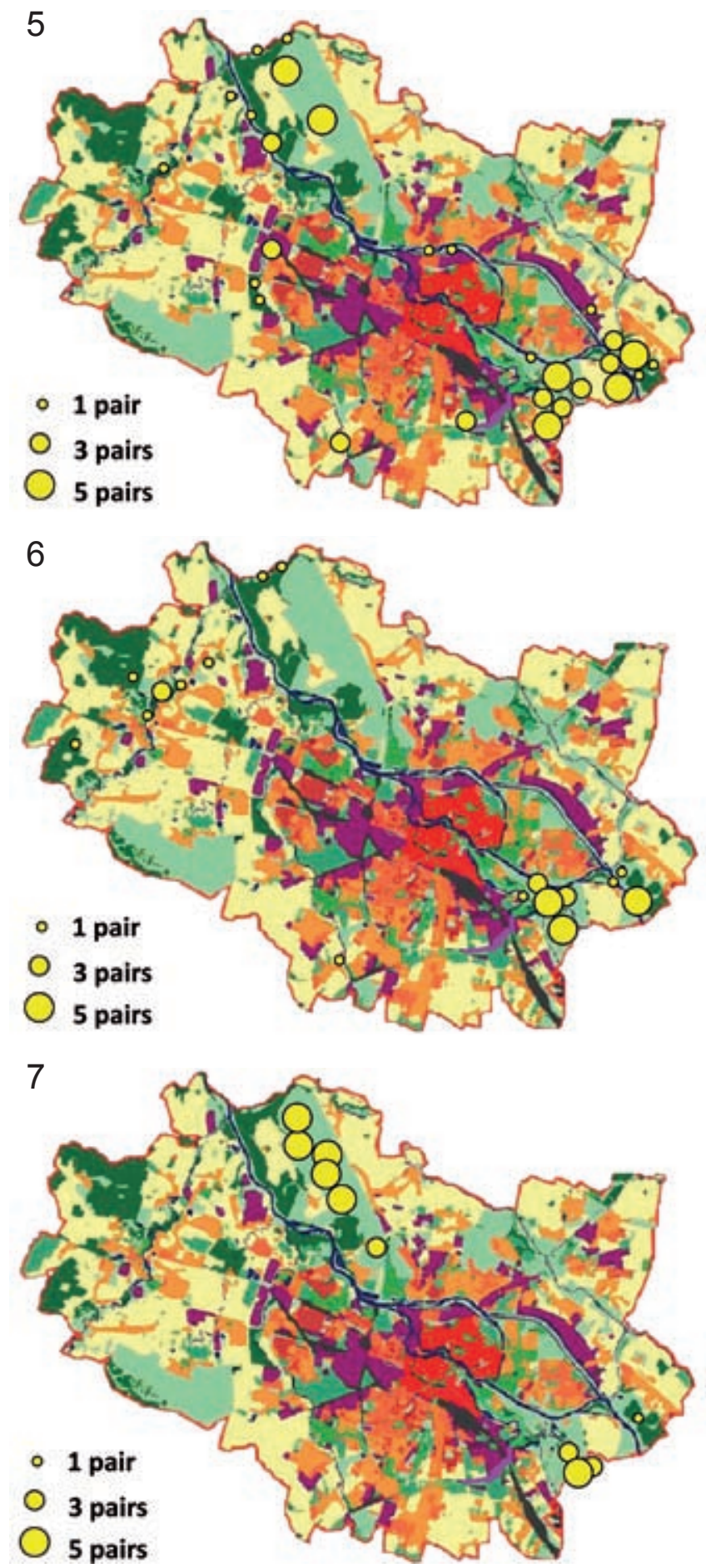

Fig. 2-7 - Distribution of breeding pairs in the city of Wrocław during the years 2002-2010. / Distribuzione delle coppie riproduttive nella città di Breslavia negli anni 2002-2010. 2) Barred Warbler / Bigia padovana; 3) Penduline Tit / Pendolino; 4) Stonechat / Saltimpalo; 5) Grasshopper Warbler / Forapaglie macchiettato; 6) River Warbler / Locustella fluviatile; 7) Savi's Warbler / Salciaiola. Black) railway; purple) industry areas; red) densely built-up areas; orange) loosely built-up areas; dark green) urbanized woods; light green) parks; bright green) grassy areas; yellow) arable grounds. / Nero) ferrovia, viola) aree industriali, rosso) aree densamente popolate, arancione) aree scarsamente popolate, verde scuro) boschi urbanizzati, verde chiaro) parchi, verde brillante) aree erbose, giallo) seminativi. (Source / Fonte, Smolnicki \& Szykasiuk, 2002). 

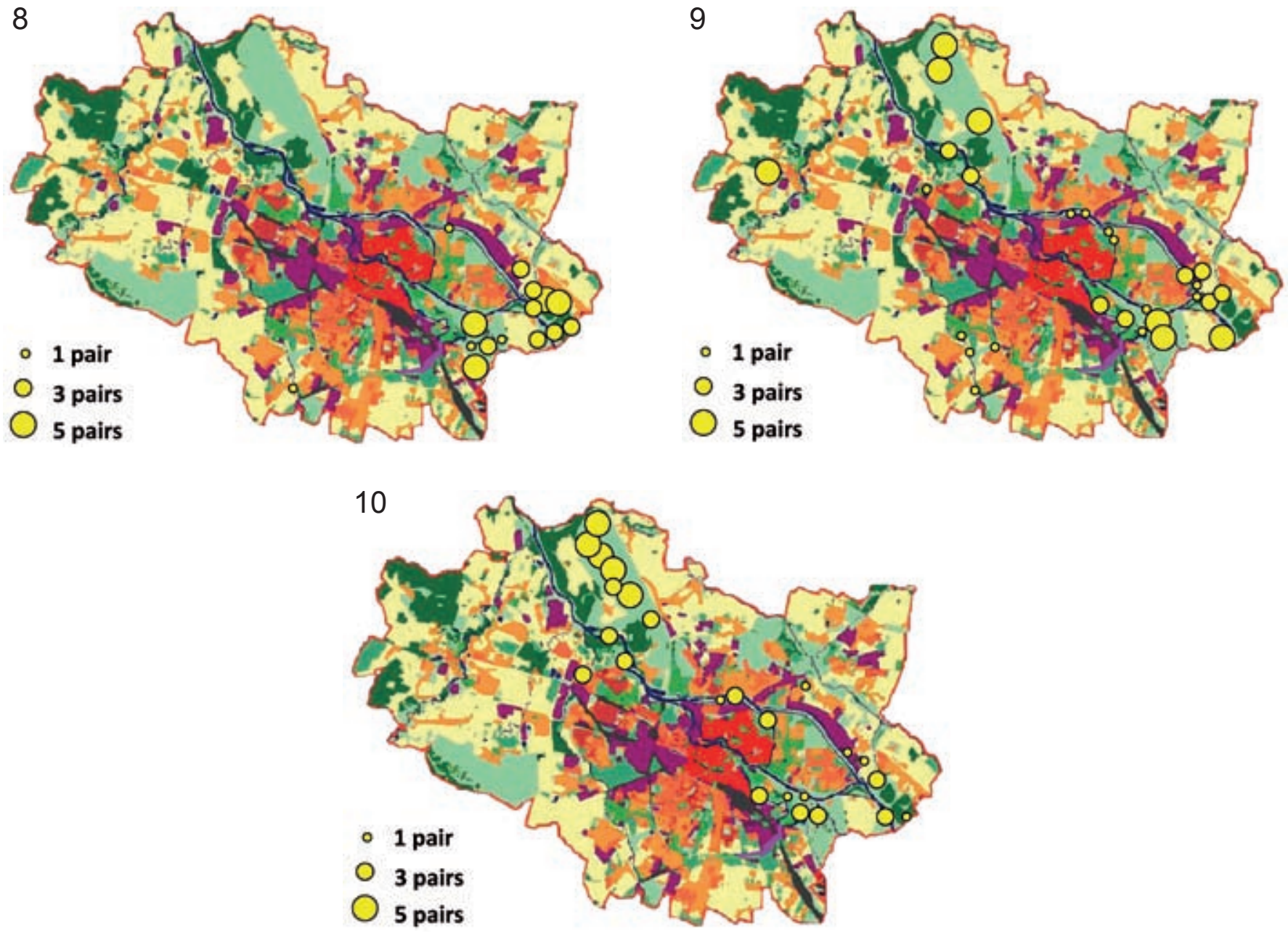

Figs. 8-10 - Distribution of breeding pairs in the city of Wrocław during the years 2002-2010. / Distribuzione delle coppie riproduttive nella città di Breslavia negli anni 2002-2010. 8) Great Reed Warbler / Cannareccione. 9) Eurasian Reed Warbler / Cannaiola comune. 10) Sedge Warbler / Forapaglie.

Black) railway; purple) industry areas; red) densely built-up areas; orange) loosely built-up areas; dark green) urbanized woods; light green) parks; bright green) grassy areas; yellow) arable grounds. / Nero) ferrovia, viola) aree industriali, rosso) aree densamente popolate, arancione) aree scarsamente popolate, verde scuro) boschi urbanizzati, verde chiaro) parchi, verde brillante) aree erbose, giallo) seminativi. (Source / Fonte, Smolnicki \& Szykasiuk, 2002).

\section{DISCUSSION}

The densities recorded in Wrocław were significantly higher than in Niemodlin countryside for most species studied in the same period (Tab. 1). Niemodlin countryside, situated c. $100 \mathrm{~km}$ SE of Wrocław, comprises a lowland rural area of similar size (c. $300 \mathrm{~km}^{2}$ ) and habitats (numerous fishponds, rivers and canals, wetlands and meadows) (Kopij, 2016a). Also in the neighbouring Nysa Land (720 $\mathrm{km}^{2}$ ), where four large water reservoirs and numerous fish-pods are situated, densities of most bird species in the same period were much lower than in Wrocław (Kopij, 2012) (Tab. 2).

In comparison with the years 1978-1987 (Dyrcz et al., 1991), the numbers of breeding pairs of the Stonechat have dramatically increased in Wrocław. Also the number of the Penduline Tit breeding pairs was higher in 2002-2010 (this study) than in 1978-1987 (Dyrcz et al., 1991). Unfortunately, due to the lack of quantitative data from the past, population trends for other species cannot be established.
The wetlands in NW part of Wrocław are under gradual transformation to urbanized habitats, roads, buildings, sport fields and other recreational areas. So, in the next few decades, larger parts of this area may disappear from the city's landscape. On the other hand, the wetlands in SE part are not threatened by transformation/degradation in the near future. They play an important role in the city as water retention areas and as anti-flooded polders. It is, therefore, unlikely that in the near future they will be altered or diminished in size. Furthermore, most of the area is excluded from direct human management, and being inaccessible for public, they may attract numerous species associated with water, wetlands and grasslands. Fortunately, the wetlands are already protected by the Bird Directive (79/409/EEC) as Special Protection Area, and it is fully justified to retain such status or even elevate it to the rank of nature reserve.

The peri-urban wetland areas in Wrocław play, therefore, an important role in the protection of trans-Saharan migrant species, such as those from the genus Acrocepha- 
Tab. 1 - Number of breeding pairs of selected passerine species associated with marshlands and meadows in the city of Wroclaw $\left(292 \mathrm{~km}^{2}\right)$ and in the neighbouring Niemodlin countryside $\left(300 \mathrm{~km}^{2}\right)$, with a similar proportion of wetlands. / Numero di coppie riproduttive di passeriformi associati a terreni paludosi e prati nella città di Breslavia $\left(292 \mathrm{~km}^{2}\right)$ e nella campagna di Niemodlin $\left(300 \mathrm{~km}^{2}\right)$.

\begin{tabular}{|l|c|c|c|c|}
\hline Species & Niemodlin countryside & Wroclaw City & $\boldsymbol{\chi}^{\mathbf{2}}$-test & P \\
\hline Stonechat & 16 & 33 & 5.9 & $<0.05$ \\
\hline Grasshopper Warbler & 27 & 70 & 19.1 & $<0.01$ \\
\hline River Warbler & 16 & 35 & 7.1 & $<0.01$ \\
\hline Savi's Warbler & 8 & 40 & 21.3 & $<0.01$ \\
\hline Great Reed Warbler & $57-70$ & 72 & 0.5 & $>\mathbf{0 . 0 5}$ \\
\hline Eurasian Reed Warbler & $124-150$ & 68 & 11.6 & $<\mathbf{0 . 0 1}$ \\
\hline Sedge Warbler & $>6$ & 43 & 27.9 & $<0.01$ \\
\hline Barred Warbler & $>1$ & 5 & - & $<0.05$ \\
\hline Penduline Tit & $>6$ & 17 & 5.3 & \\
\hline Red-backed Shrike & common & 68 & - & \\
\hline
\end{tabular}

Tab. 2 - Proportions among Acrocephalus and Locustella species in Wrocław and in neighbouring areas. For each genera, total number of pairs have been reported. Nysa Land: Kopij (2012); Niemodlin Land: Kopij (2016); Wrocław: this study. / Proporzioni tra specie di Acrocephalus e Locustella a Breslavia e nelle zone limitrofe. Per ogni genere è stato segnalato il numero totale di coppie. Nysa Land: Kopij (2012); Niemodlin Land: Kopij (2016); Breslavia: questo studio.

\begin{tabular}{|l|c|c|c|}
\hline Species & Nysa Land & Niemodlin countryside & Wroclaw city \\
\hline Acrocephalus (N. of pairs) & 92 & 207 & 183 \\
\hline Great Reed Warbler & 0.54 & 0.31 & 0.39 \\
\hline Eurasian Reed Warbler & 0.16 & 0.66 & 0.37 \\
\hline Sedge Warbler & 0.29 & 0.03 & 0.24 \\
\hline Locustella (N. of pairs) & 66 & 51 & 155 \\
\hline Grasshopper Warbler & 0.61 & 0.53 & 0.48 \\
\hline River Warbler & 0.34 & 0.31 & 0.24 \\
\hline Savi's Warbler & 0.05 & 0.16 & 0.28 \\
\hline
\end{tabular}

lus and Locustella. The Marsh Warbler Acrocephalus palustris was not censused in this study, but it was abundant in most marshland and meadow habitats, especially along canals and rivers.

\section{REFERENCES}

Angelici C., Marini F., Battisi C., Bertolino S., Capizzi D. \& Monaco A., 2012 - Cumulative impact of rats and coypu on nesting waterbirds: first evidences from a small Mediterranean wetland (central Italy). Vie et Milieu, 62: 137-141.

Bibby C. J., Burgess N. D. \& Hill D. A., 2012 - Bird census techniques. Academic Press, London.

BirdLife International, 1994 - Birds in Europe. Population estimates, trends and conservation status. BirdLife International, Cambridge (UK).
Boyer T. \& Polasky S., 2004 - Valuing urban wetlands: a review of non-market valuation studies. Wetlands, 24: 744-755.

Dyrcz A., Grabinski W., Stawarczyk T. \& Witkowski J., 1991 - Ptaki Śląska. Monografia faunistyczna. Uniwersytet Wrocławski, Wrocław.

Kopij G., 2004 - Ptaki lęgowe Wielkiej Wyspy Szczytnickiego Zespołu Przyrodniczo-Krajobrazowego we Wrocławiu. Zeszyty Naukowe UP Wrocław, Zootechnika, 50 (488): 187 204.

Kopij G., 2005 - Ptaki lęgowe zachodniej części Sródmieścia we Wrocławiu. Zeszyty Naukowe UP Wrocław, Zootechnika, 53: 87-99.

Kopij G., 2007 - Ptaki Starego Miasta we Wrocławiu. Zeszyty Naukowe UP Wrocław, Zootechnika, 55, 93105. 
Kopij G., 2008 - Awifauna legowa Obszaru Specjanje Ochrony Natura 2000 "Grądy Odrzańskie" we Wrocławiu. Parki Narodowe i Rezerwaty Przyrody, 27: 95-114.

Kopij G., 2010 - Ptaki lęgowe północno-wschodniej części dzielnicy Fabrycznej we Wrocławiu. Zeszyty Naukowe UP Wrocław, Biologia i Hodowla Zwierząt, 60: 77-96.

Kopij G., 2012 - Awifauna lęgowa Ziemi Nyskiej. Chr. Przyr. Ojcz., 68: 259-287.

Kopij G., 2014a - Ptaki lęgowe klina zieleni w gradiencie urbanizacji na Krzykach we Wrocławiu. In: Animal, Man and the City. Interactions and Relationships. Indykiewicz P. \& Bohner J. (eds.). Urban Fauna (Bydgoszcz), 6: 195-207.

Kopij G., 2014b - Breeding bird community of a large cemetery in a Central European city in 1969 and 40 years later. Vogelwelt, 135: 67-74.

Kopij G., 2014c. - Population densities of birds breeding in urbanized habitats in the Grabiszyn district in the city of Wrocław. Acta Musei Silesiae Scientiae Naturales, 63: 139-150.

Kopij G., 2016a - Breeding avifauna of Niemodlin countryside (SW Poland) during the years 2002-2007, and its changes over the last 56 years (1962-2007). Acta Musei Silesiae Scientiae Naturales, 65: 179-192.

Kopij G., 2016b - Changes in the number of nesting pairs and breeding success of the White Stork Ciconia ciconia in a large city and a neighbouring rural area in SW Poland. Ornis Hungarica, 24 (2).

Kopij G., 2016c - Breeding bird assemblage in a mosaic of urbanized habitats in a Central European city. Vestnik Zoologii, 50: 163-172.

Kopij, G., 2017 - Expansion of alien carnivore and ungulates species in SW Poland. Russian Journal of Biological Invasion, 8: 290-299.

Orłowski G., Górka W. \& Sęk M., 2008 - Środowisko i liczebność populacji lęgowej podróżniczka Luscinia svecica we Wrocławiu w latach 2004 i 2007. Notatki Ornitologiczne, 49: 13-20.

Orłowski G. \& Sęk M., 2005 - Seminatural reedbeds as breeding habitat of Bluethroat (Luscinia svecica L.) on sewage farm in Wrocław city (South-western Poland). Polish Journal of Ecology, 53: 135-142.

Smolnicki K. \& Szykasiuk M. (eds.), 2002 - Środowisko Wrocławia. Dolnoślaska Fundacja Ekorozwoju, Wrocław: 74-98.

Słychan M., 1996 - Ptaki pól irygacyjnych Wrocławia. Ptaki Śląska, 11: 133-150. 